\title{
MODEL KONSEPTUAL PEMETAAN WILAYAH POTENSIAL HILIRISASI KELAPA SAWIT BERDASARKAN DAYA SAING DAN KELEMBAGAAN PETANI SWADAYA
}

\section{CONCEPTUAL MODEL OF POTENTIAL AREAS MAPPING FOR PALM OIL DOWNSTREAMBASED ON SMALLHODER FARMERS' COMPETITIVENESS AND INSTITUTIONS}

\author{
Safriyana*), Marimin, Elisa Anggraeni, Illah Sailah \\ Program Studi Teknologi Industri Pertanian, Sekolah Pascasarjana IPB University \\ Kampus IPB Darmaga, PO Box 220 Bogor 16002, Indonesia \\ E-mail : anayirfas@apps.ipb.ac.id \\ Makalah: Diterima 1 September 2018; Diperbaiki 2 Januari 2019; Disetujui 15 Januari 2019
}

\begin{abstract}
Palm oil as a leading commodity that has a role in national development, continues to experience increased demand, dueto it beneficial in various fields of needs. However, the problems and challenges have prompted the government to improve its competitiveness through in-country palm oil downstream policies. One of the policies is smallholder farmers oil palm's replanting to support palm oil downstream sector and to increase the smallholder farmers' social welfare. The crucial thing that is important to note and become the focus of this research is the linkage of the smallholder farmers in support palm oil downstream policies, because the smallholder farmers as the main raw materials supplierto downstream palm oil agroindustry are still obstructed, in relation to geographical conditions, its competitiveness, and its institutions. Therefore, a study was needed to produce an integrated palm oil downstream strategic planning related to the area, competitiveness, and institutional of palm oil smallholder farmers, in determining the potential area model for the development of palm oil downstream in order to have comparative and competitive advantages. The conceptual model of palm oil downstream 'spotential areas that uses spatial analysis through geographical information system was used to obtain an overview of the palm oil condition, while competitiveness conceptual modelling uses Diamond Portercompetitiveness index, and the institutional modelling uses Interpretative Structure Modeling (ISM) method to obtain the influential variables as the key elements in the palm oil downstream that affect the smallholder farmers position.
\end{abstract}

Keywords: competitiveness, palm oil downstream, institutional, area mapping, smallholder farmers

\section{ABSTRAK}

Kelapa sawit sebagai komoditas unggulan yang memiliki peran dalam pembangunan nasional, terus mengalami peningkatan permintaan, karena dapat digunakan dalam berbagai bidang kebutuhan.Namun, permasalahan terhadap tantangan ekspor kelapa sawit mendorong pemerintah untuk meningkatkan kemampuan daya saing melalui kebijakan hilirisasi kelapa sawit di dalam negeri. Salah satu kebijakan tersebut adalah peremajaan kelapa sawit petani swadaya untuk menunjang sektor hilir kelapa sawit dan peningkatan kesejahteraan sosial petani swadaya kelapa sawit. Hal krusial yang penting diperhatikan dan menjadi fokus penelitian ini adalah keterhubungan petani swadaya dalam mendukung kebijakan tersebut, dikarenakan petani swadaya sebagai penyedia bahan baku industri hilir kelapa sawit masih terhambat, terkait kondisi lahan, posisi daya saing, dan kelembagaannya. Oleh sebab itu, diperlukan suatu kajian untuk menghasilkan perencanaan strategis hilirisasi kelapa sawit secara terintegrasi yang terkait antara wilayah, daya saing, dan kelembagaan petani swadaya kelapa sawit dalam penentuan wilayah potensial untuk pengembangan hilirisasi kelapa sawit agar memiliki keunggulan komparatif dan kompetitif. Model konseptual pemetaan wilayah potensial hilirisasi kelapa sawit menggunakan analisis spasial pada sistem informasi geografis digunakan untuk memperoleh gambaran terhadap kondisi lahan kelapa sawit, sedangkan pemodelan konseptual daya saing dengan Diamond Porterindeks daya saing,dan model konspetual kelembagaan dengan bantuan Interpretative Structure Modelling (ISM) digunakan untuk memperoleh variabel-variabel yang berpengaruh sebagai elemen kunci dalam hilirisasi kelapa sawit yang mempengaruhi posisi petani swadaya.

Kata kunci: daya saing, hilirisasi kelapa sawit, kelembagaan, pemetaan wilayah, petani swadaya

\section{PENDAHULUAN}

Tingginya permintaan terhadap kelapa sawit yang dipengaruhi oleh luasnya penggunaan kelapa sawit dalam berbagai bidang, mulai dari kebutuhan konsumsi hingga substitusi energi, prospek komoditi kelapa sawit dalam hal ini mendorong pemerintah dan pelaku industri untuk meningkatkan kemampuan daya saing dan keberlanjutan terhadap kelapa sawit (Hadiguna et al., 2008). Upaya peningkatan terhadap kemampuan dayasaing dan keberlanjutan ini dipengaruhi secara langsung oleh pemenuhan kebutuhan baku yang disediakan dari perkebunan kelapa sawit untuk 
diolah oleh berbagai industri. Sumber bahan baku untuk industri kelapa sawit yang berasal dari lahan sawit seluas 10,95 juta hektar, terbagi menjadi tiga sumber potensial, yaitu dari petani atau perkebunan rakyat, perusahaan milik negara, dan perkebunan milik swasta. Berdasarkan pada luas areal lahan dan produktivitas, diketahui bahwa sekitar 23\% dari lahan kelapa sawit merupakan milik petani swadaya dengan rendemen yang cukup rendah (2-3 ton/hektar/tahun) dibandingkan dengan perkebunan swasta dan petani plasma.

Hal tersebut menjadi suatu kesenjangan dalam konsep daya saing dan keberlanjutan pemenuhan pasokan bahan baku kelapa sawit dari perkebunan rakyat sehingga berimbas pada industri hilir kelapa sawit. Hal ini sesuai dengan hasil penelitian Hidayat et al. (2012) yang menyebutkan bahwa produktivitas petani rendah dan terdapat kesenjangan dalam keuntungan per hektar bila dibandingkan dengan perkebunan milik swasta. Kesenjangan yang dialami petani kelapa sawit karena kurangnya akses terhadap layanan dan perencanaan yang memadai bila dibandingkan dengan petani mitra (plasma) perusahaan (Alwarritzi et al., 2015). Terkait ulasan mengenai produktivitas lahan dan tingginya permintaan terhadap kelapa sawit tersebut, maka diperlukan berbagai upaya untuk mempertahankan dan menjamin kontinuitas pasokan bahan baku kelapa sawit sebagai dasar dalam pemenuhan terhadap permintaan industri hilir kelapa sawit yang turut berkontribusi dalam pembangunan nasional. Salah satunya dengan pembentukan dan penguatan kelembagaan petani rakyat karena petani merupakan ujung tombak keberhasilan dalam upaya pengembangan hilirisasi kelapa sawit secara berkelanjutan. Kelembagaan ini dimaksudkan untuk meningkatkan posisi tawar, akses perbankan, input produksi dan pemasaran dengan melaksanakan berbagai kegiatan untuk menghasilkan kelembagaan yang memadai dan efektif (FOKSBI, 2017).

Permasalahan dalam produktivitas dan keberlanjutan perkebunan kelapa sawit pada lahan yang dimiliki oleh petani swadaya, pemenuhan pasokan tanaman kelapa sawit akan bergantung pada perkebunan rakyat (Saragih, 2017), sehingga pemerintah melalui Badan Pengelola Dana Perkebunan Kelapa Sawit (BPDPKS) mencanangkan upaya peremajaan kelapa sawit guna mendukung keberlanjutan hilirisasi kelapa sawit dalam kontuinitas pasokan kelapa sawit dan peningkatan produktivitas kelapa sawit dari petani swadaya. Kegiatan tersebut diharapkan mampu menyerap tenaga kerja, pertumbuhan produk domestik bruto (PDB), dan menurunkan tingkat kemiskinan di Indonesia, serta membawa petani ke dalam masyarakat ekonomi kelas menengah (Saragih, 2017; BPDPKS, 2018). Hal ini juga terkait dengan Rencana Induk Pembangunan Industri Nasional 2015-2035 (RIPIN) (Kemenperin, 2015) yang menyebutkan bahwa aspek-aspek yang perlu diperhatikan dalam karakterisasi dan relevansi untuk pembangunan industri nasional melalui penyiapan standarisasi dan infrastruktur industri termasuk perwilayahan industri yang disebut sebagai Wilayah Pusat Pertumbuhan Industri (WPPI).

Dalam pelaksanaannya, terdapat beberapa tantangan antara lain sertifikasi lahan petani swadaya, kebutuhan modal yang tinggi terhadap peremajaan kelapa sawit, rendahnya dayasaing petani, serta kelembagaan yang tidak aktif dalam fungsinya untuk mewadahi kegiatan peremajaan kelapa sawit (PPKS, 2017; Wei, 2017). Terkait dukungan terhadap hilirisasi kelapa sawit, peran petani swadaya dalam mendukung hilirisasi kelapa sawit melalui penyediaan bahan baku yang memenuhi standar kualitas untuk keberlanjutan hilirisasi kelapa sawit. Sehingga, walaupun petani swadaya tidak berperan langsung dalam pengolahan kelapa sawit, namun memiliki peran penting untuk menghasilkan kelapa sawit yang memenuhi standarisasi untuk kebutuhan industri hilirnya. Hal tersebut menjadi suatu tantangan yang perlu dikaji karena kebutuhan pasokan kelapa sawit yang terus meningkat seiring kemjauan industri hilirnya tidak diimbangi oleh pemenuhan kualitas yang baik dari segi bahan baku.

Berdasarkan pada paparan permasalahan, tantangan, dan kebijakan pemerintah tersebut, maka dibutuhkan suatu model perencanaan untuk hilirisasi kelapa sawit secara terintegrasi dari bagian hulu hingga hilir. Model konseptual tersebut dapat menjadi sebagai penunjang aktivitas dalam pengambilan keputusan untuk hilirisasi kelapa sawit di Indonesia yang berkelanjutan dan memiliki daya saing sebagai strategi yang dapat menjawab arah perkembangan hilirisasi kelapa sawit di Indonesia. Pengembangan hilirisasi kelapa sawit tersebut diintegrasikan sesuai dengan kebijakan pemerintah, yang memerlukan suatu pengembangan keputusan spasial sebagai pertimbangan untuk hilirisasi kelapa sawit petani swadaya secara geografis, serta kelembagaan sebagai media petani swadaya dalam membangun kemitraan dengan pengusaha dan industri serta kontinuitas aliran kelapa sawit. Sehingga, dapat dirumuskan bahwa hubungan keruangan perkebunan kelapa sawit sebagai suatu sistem informasi geografis dapat mendukung pengambilan keputusan untuk keberlanjutan hilirisasi kelapa sawit melalui pemetaan wilayah yang dilakukan. Selain itu, pemetaan wilayah ini perlu didukung oleh pemodelan daya saing dan kelembagaan pada petani swadaya yang secara terintegrasi dapat mendukung upaya pelaksanaan pengembangan hilirisasi kelapa sawit.

Adapun tujuan pelaksanaan penelitian antara lain, mengidentifikasi pemetaan perkebunan kelapa sawit petani swadaya sebagai justifikasi awal untuk sistem informasi geografis yang memuat data spasial dan data atributnya, mengidentifikasi dan 
menstrukturisasi model konseptual kondisi kelembagaan petani swadaya kelapa sawit, dan mengidentifikasi model konseptual daya saing perkebunan kelapa sawit petani swadaya kelapa dalam mendukung hilirisasi kelapa sawit berdasarkan pada indikator Diamond Porter. Ruang lingkup dalam penelitian dilakukan pada perkebunan kelapa sawit milik petani swadaya di Kabupaten Kampar, Provinsi Riau untuk keseluruhan analisis dan pengembangan model. Namun, untuk model pemetaan yang ditampilkan pada naskah dibatasi pada ruang lingkup Kecamatan Tapung, sebagai model konseptual untuk model spasial untuk tingkat potensial wilayah perkebunan kelapa sawit petani swadaya.

\section{METODE PENELITIAN}

\section{Kerangka Pemikiran}

Permasalahan proses hilirisasi kelapa sawit dapat dipandang secara luas, tidak hanya berdasarkan pada variasi permintaan pasar terhadap produk hilir kelapa sawit dan kemampuan produksinya di dalam negeri. Lebih dari itu, dalam upaya pengembangan hilirisasi kelapa sawit, diperlukan suatu pendekatan khusus yang memandang upaya hilirisasi kelapa sawit dari segi penyediaan bahan baku kelapa sawit yang memiliki kualitas sesuai untuk hilirisasi. Peran petani swadaya sebagai aktor utama dalam penyediaan bahan baku kelapa sawit dipandang menjadi hal krusial karena adanya permasalahan mutu dari kelapa sawit dari petani swadaya dan permasalahan untuk kontinuitas hilirisasi kelapa sawit. Permasalahan petani swadaya dalam memenuhi kualitas kelapa sawit yang dibutuhkan industri hilir dipengaruhi oleh kondisi tanaman pada lokasi tanam, posisi tawar petani swadaya, dan kurangnya akses terhadap informasi dan permodalan. Mengacu pada permasalahan tersebut, sudut pandang untuk hilirisasi kelapa sawit perlu diselesaikan melalui suatu pendekatan terintegrasi untuk peningkatan posisi petani swadaya melalui pemodelan pemetaan wilayah perkebunan kelapa sawit milik petani swadaya. Pemodelan pemetaan perkebunan kelapa sawit tersebut juga didukung dengan pemodelan terhadap kondisi daya saing dan kelembagaan petani swadaya. Pemodelan terintegratif tersebut lebih lanjut dapat dijadikan dasar dalam pertimbangan untuk pengambilan keputusan keberlanjutan hilirisasi kelapa sawit, khususnya hasil kelapa sawit petani swadaya.

Strukturisasi kelembagaan kelapa sawit petani swadaya dilakukan dalam tujuan untuk menilai keterkaitan antara masing-masing petani swadaya dalam pemenuhan tujuan, kebutuhan, dan kendala pada kelompok petani swadaya sehingga dapat ditentukan jenis dan pola hubungan masingmasing pelaku yang saling terkait dan aliran bahan baku berupa hasil pemanenan kelapa sawit hingga pengolahan primer dan sekunder yang dilakukan dari hasil panen tersebut sehingga dapat dirumuskan suatu model kelembagaan yang akan dibangun sebagai sebuah masukan dalam perencanaan hilirisasi kelapa sawit berkelanjutan. Penentuan posisi daya saing petani swadaya juga dilakukan pada kelembagaan petani swadaya sehingga dapat diketahui permasalahan, tantangan, dan kinerja petani kelapa sawit swadaya yang menjadi komponen dalam menentukan posisi daya saingnya.

Pemodelan integratif terhadap hilirisasi kelapa sawit yang berfokus pada pemetaan wilayah, kelembagaan, dan daya saing petani swadaya kelapa sawit dalam tujuan tercapainya pengembangan hilirisasi kelapa sawit khususnya industri kecil menengah menjadi suatu langkah strategis dalam menyikapi program hilirisasi kelapa sawit yang tepat sasaran dan tepat guna. Terkait hal itu, maka permasalahan-permasalahan hilirisasi kelapa sawit yang memiliki sifat kompleksitas dan ketidakpastian ini membutuhkan suatu pendekatan sistem yang terintegrasi untuk penyelesaian permasalahan dan pemberian solusi. Secara kompeherensif, keseluruhan model yang digunakan dalam mendukung perencanaan strategis hilirisasi kelapa sawit secara berkelanjutan tersebut dimodelkan dalam model pemetaan wilayah potensial pengembangan hilirisasi kelapa sawit berdasarkan daya saing dan kelembagaan petani swadaya yang interaktif dan solutif. Keseluruhan kerangka pemikiran penelitian yang telah diuraikan tersebut dapat dilihat pada Gambar 1, sedangkan metode atau pendekatan dan keluaran dari setiap tahapan penelitian dapat dilihat pada Tabel 1 .

\section{Tata Laksana Penelitian \\ Identifikasi Sistem}

Identifikasi sistem yang terdiri atas analisis kebutuhan yang direpresentasikan dalam bentuk diagram sebab akibat dan diagram input output (Marimin dan Maghfiroh, 2010). Analisis kebutuhan berkaitan dengan kebutuhan elemen dalam sistem yang dalam penelitian ini berkaitan dengan keterhubungan petani swadaya kelapa sawit dalam peranannya sebagai penyedia bahan baku untuk industri. Identifikasi dan formulasi mengenai permasalahan dalam hilirisasi kelapa sawit berisikan tantangan-tantangan untuk peningkatan peranan petani swadaya kelapa sawit dalam mendukung kemandirian hilirisasi kelapa sawit.

\section{Model Pemetaan Wilayah Perkebunan Kelapa Sawit Petani Swadaya}

Istilah sistem informasi geografis dibangun berdasarkan pada kondisi spasial yang mengarah pada spesifikasi lokasi dalam suatu ruang. Ruang tersebut berupa fisik, budaya, dan ekonomi alamiah yang ditampilkan dalam suatu peta dua dimensi yang memberikan representatif sesuai dengan kenyataan dunia nyata yang diwakilkan oleh simbol, warna, dan gaya garis (Zulafwan, 2016). 


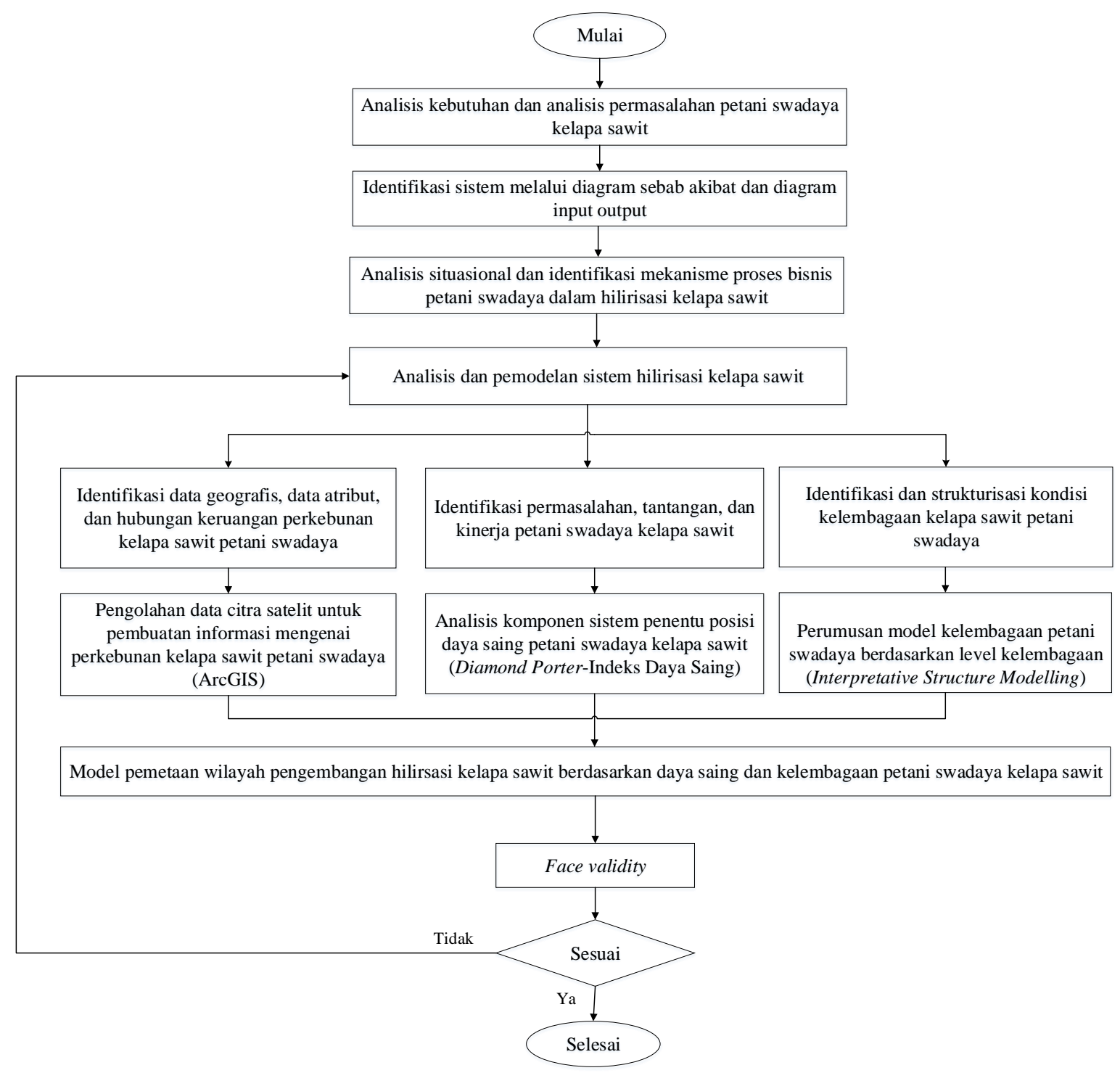

Gambar 1. Diagram alir prosedur penelitian

Objek yang merepresentasikan dunia nyata tersebut terdiri atas dua elemen, yaitu data spasial dan data atribut. Data spasial ditunjukkan dalam bentuk titik, garis, dan sudut, serta disimpan dalam bentuk raster dan vector yang biasanya diperoleh dari survei lapangan menggunakan GPS (Global Positioning System) ataupun representasi gambar satelit. Data atribut adalah data pelengkap dari data spasial yang mendeskripsikan objek geografis dalam bentuk tabel seperti populasi di suatu lokasi dan tipe penggunaan lahan (Malczewski, 1999). Terdapat lima komponen utama dalam sistem informasi geografis (Harmon dan Anderson dalam Akmal et al., 2018), antara lain: (1) pengguna yang menjalankan sistem, (2) aplikasi yang digunakan untuk mengolah data menjadi informasi, (3) data yang digunakan berupa data grafis dan data atribut, (4) perangkat lunak berupa aplikasi yang memiliki kemampuan pengelolaan dan penayangan data spasial, dan (5) perangkat keras yang dibutuhkan untuk menjalankan sistem.
Prahasta (2001) menyatakan bahwa sistem informasi geografis memiliki kemampuan dalam menyajikan wilayah dalam bentuk referensi geografis seperti garis lintang dan bujur, menyajikan letak suatu aktivitas dalam wilayah sebagai hasil analisis ruang, menyajikan perubahan ruang secara temporal dan kecenderungan, menyajikan hasil analisis spasial terhadap kegiatan tertentu, serta memadukannya dengan informasi lainnya termasuk sosial, budaya, dan hukum. Pengolahan data spasial dan data atribut pada pemetaan wilayah perkebunan kelapa sawit petani swadaya ini dilakukan dengan bantuan software ArcGIS dan peta citra digital yang menampilkan dan menyimpan informasi spasial serta mengembangkan aplikasi (Teniwut et al., 2017). Sebelum dilakukan pengolahan, perlu dipastikan bahwa ketersediaan data spasial merupakan data penting untuk menghasilkan informasi terkait pemetaan wilayah perkebunan kelapa sawit petani swadaya pada waktu dan tempat yang pasti. 
Tabel 1. Model/pendekatan pada setiap tahapan penelitian

\begin{tabular}{|c|c|c|c|}
\hline Tahapan penelitian & Sub tahapan & Metode/pendekatan & Keluaran \\
\hline \multirow[t]{2}{*}{$\begin{array}{l}\text { Analisis sistem pemodelan } \\
\text { pemetaan wilayah } \\
\text { hilirisasi kelapa sawit } \\
\text { secara terintegrasi }\end{array}$} & $\begin{array}{l}\text { Analisis kebutuhan sistem } \\
\text { Formulasi permasalahan }\end{array}$ & Pendekatan sistem & $\begin{array}{l}\text { Kebutuhan dan tantangan } \\
\text { dalam pemodelan pemetaan } \\
\text { wilayah hilirisasi kelapa } \\
\text { sawit }\end{array}$ \\
\hline & Identifikasi sistem & Analisis deskriptif & $\begin{array}{l}\text { Diagram input-output } \\
\text { Diagram sebab-akibat }\end{array}$ \\
\hline \multirow{3}{*}{$\begin{array}{l}\text { Identifikasi data geografis, } \\
\text { data atribut, dan hubungan } \\
\text { keruangan perkebunan } \\
\text { kelapa sawit petani } \\
\text { swadaya }\end{array}$} & $\begin{array}{l}\text { Pengumpulan peta wilayah } \\
\text { perkebunan kelapa sawit } \\
\text { petani swadaya }\end{array}$ & $\begin{array}{l}\text { Analisis data } \\
\text { geospasial } \\
\text { menggunakan } \\
\text { software ArcGIS }\end{array}$ & $\begin{array}{l}\text { Peta wilayah dan kondisi } \\
\text { lahan perkebunan kelapa } \\
\text { sawit petani swadaya }\end{array}$ \\
\hline & $\begin{array}{l}\text { Pendefenisian data citra } \\
\text { satelit }\end{array}$ & & $\begin{array}{l}\text { Penampakan tiga dimensi } \\
\text { perkebunan kelapa sawit dan } \\
\text { kondisi jalur transportasi }\end{array}$ \\
\hline & $\begin{array}{l}\text { Digitasi pemetaan wilayah } \\
\text { perkebunan kelapa sawit } \\
\text { petani swadaya }\end{array}$ & & $\begin{array}{l}\text { Model pemetaan wilayah } \\
\text { pengembangan hilirisasi } \\
\text { kelapa sawit }\end{array}$ \\
\hline \multirow[t]{2}{*}{$\begin{array}{l}\text { Identifikasi dan } \\
\text { strukturisasi kondisi } \\
\text { kelembagaan kelapa sawit } \\
\text { petani swadaya }\end{array}$} & $\begin{array}{l}\text { Identifikasi elemen dan sub- } \\
\text { elemen untuk kelembagaan } \\
\text { petani swadaya }\end{array}$ & $\begin{array}{l}\text { Interpretative } \\
\text { Structure Modelling } \\
\text { (ISM) }\end{array}$ & $\begin{array}{l}\text { Elemen dan sub-elemen } \\
\text { kunci dalam kelembagaan } \\
\text { petani swadaya untuk } \\
\text { hilirisasi kelapa sawit }\end{array}$ \\
\hline & $\begin{array}{l}\text { Pembobotan sub-elemen } \\
\text { untuk kelembagaan petani } \\
\text { swadaya }\end{array}$ & & $\begin{array}{l}\text { Hasil terpilih sebagai faktor } \\
\text { penentu dalam model } \\
\text { kelembagaan untuk petani } \\
\text { swadaya }\end{array}$ \\
\hline $\begin{array}{l}\text { Identifikasi posisi, } \\
\text { tantangan, dan kinerja } \\
\text { petani swadaya kelapa } \\
\text { sawit }\end{array}$ & $\begin{array}{l}\text { Identifikasi dimensi dari } \\
\text { masing-masing indikator } \\
\text { dalam Diamond Porter }\end{array}$ & $\begin{array}{l}\text { Model konseptual } \\
\text { Diamond Porter }\end{array}$ & $\begin{array}{l}\text { Dimensi yang berpengaruh } \\
\text { dalam daya saing petani } \\
\text { swadaya }\end{array}$ \\
\hline $\begin{array}{l}\text { Pengukuran indeks daya } \\
\text { saing petani swadaya } \\
\text { dalam mendukung } \\
\text { hilirisasi kelapa sawit }\end{array}$ & $\begin{array}{l}\text { Pembobotan untuk indikator } \\
\text { dan dimensi daya saing } \\
\text { petani swadaya }\end{array}$ & Indeks daya saing & $\begin{array}{l}\text { Hasil penilaian indeks daya } \\
\text { saing petani swadaya kelapa } \\
\text { sawit }\end{array}$ \\
\hline
\end{tabular}

Data dalam bentuk peta perwilayahan kelapa sawit ini diperoleh dalam ekstensi shp melalui portal geospasial milik pemerintah yang disesuaikan dengan kondisi lapangan terkait lahan dan kondisi geografis kelapa sawit petani swadaya. Peta yang diolah menghasilkan informasi yang merepresentasikan dunia nyata tersebut terdiri atas dua elemen, yaitu data spasial (ditunjukkan dalam bentuk titik, garis, dan sudut yang dapat disimpan dalam bentuk raster dan vektor) serta data atribut (data pelengkap dari data spasial yang mendeskripsikan objek geografis dalam bentuk tabel seperti populasi di suatu lokasi dan tipe penggunaan lahan) sehingga menjadi suatu informasi yang membantu dalam pemecahan permasalahan kewilayahan secara terorganisisr dalam kaitan lokasi/posisi sehingga keperluan pemetaan wilayah potensial yang kompleks untuk pengembangan hilirisasi kelapa sawit berdasarkan pada lokasi sumber dayanya.

Pemetaan tingkat potensial wilayah perkebunan kelapa sawit swadaya dilakukan melalui proses pembuatan model spasial dengan melihat masing-masing indikator yang berpengaruh terhadap produktivitas dan keberlanjutan perkebunan kelapa sawit milik petani swadaya. Indikator yang dipilih dalam menentukan tingkat potensial wilayah perkebunan kelapa sawit petani swadaya ini didasarkan pada pengaruh faktor manusia dan faktor lingkungan. Selanjutnya, dilakukan proses skoring sesuai dengan standar yang telah ditentukan sesuai dengan literatur berdasarkan masing-masing kriteria untuk kesesuaian penggunaan lahan perkebunan kelapa sawit. Secara paralel, untuk pembangunan model spasial, dilakukan proses pembobotan dengan menggunakan metode AHP (Analytical Hierarchy Process). Dalam proses dilakukan pembuatan hirarki untuk menghasilkan bobot yang digunakan sebagai persamaan dalam model matematis untuk perhitungan tingkat potensial perkebunan kelapa sawit petani swadaya. Berdasarkan pada model matematis dan peta spasial yang telah dibuat, maka dapat ditentukan tingkat potensial perkebunan kelapa sawit petani swadaya berdasarkan pada bobot dan skor yang membangun model tingkat potensial perkebunan kelapa sawit petani swadaya. Berdasakan pada skor total yang diperoleh, maka tingkat potensial perkebunan kelapa sawit nantinya akan diklasifikasikan ke dalam tiga kelas, yaitu perkebunan kelapa sawit tidak potensial, perkebunan kelapa sawit berkembang, dan perkebunan kelapa sawit potensial. Selanjutnya, berdasarkan pada 
klasifikasi tersebut, dilakukan proses pemetaan tingkat potensial perkebunan kelapa sawit petani swadaya sebagai tahap akhir dari penelitian. Hasil klasifikasi tersebut diharapkan mampu memberikan suatu rekomendasi untuk pihak pengambil keputusan untuk memperbaiki dan meningkatkan perkebunan kelapa sawit petani swadaya.

Dalam tahapan penelitian yang dilakukan untuk menghasilkan pemetaan tingkat potensial perkebunan kelapa sawit petani swadaya. Tahapan praposes data, pemrosesan data, perhitungan model klasifikasi, serta pemetaan model klasifikasi menggunakan bantuan aplikasi ArcGIS 10.4, sedangkan tahapan pembuatan model klasifikasi melalui pendekatan AHP dilakukan dengan bantuan aplikasi Expert Choice 11. Berdasarkan hasil bobot yang dihasilkan dari metode AHP tersebut, dibuatkan persamaan matematik dengan bobot yang dituliskan pada koefisien masing-masing faktor dari kriteria. Persamaan matematik disusun berdasarkan skor pada hirarki yang dihasilkan, dengan rumus $\mathrm{V}=$ E $\Sigma$ wi xi $+\mathrm{H} \Sigma$ vi yi, E menyatakan kriteria lingkungan dan $\mathrm{H}$ menyatakan kriteria manusia. Setelah itu, dilakukan perhitungan untuk klasifikasi berdasarkan pada model matematis yang telah dihasilkan sebelumnya, sehingga dihasilkan skor total untuk mengklasifikasikan tingkat potensial perkebunan kelapa sawit petani swadaya. Berdasarkan skor total tersebut, dilakukan klasifikasi tingkat potensial perkebunan kelapa sawit petani swadaya dengan menggunakan persamaan sebagai berikut (Raharjo et al., 2014): rentang nilai = (nilai maksimum - nilai minimum) / jumlah kelas. Klasifikasi tingkat potensial perkebunan kelapa sawit petani swadaya dilakukan berdasarkan pada rentang nilai yang telah dihasilkan untuk selanjutnya dibuat klasifikasi dengan rentang nilai tersebut sesuai dengan jumlah kelasnya.

\section{Model Kelembagaan Petani Kelapa Sawit Swadaya}

Utama (2012) menyebutkan bahwa kelembagaan adalah suatu konsep jaringan kerjasama yang terstruktur antar beberapa pihak yang saling terkait dengan visi dan misi yang telah disepakati bersama serta menentukan tingkat efektivitas dan efisiensi dari kelembagaan tersebut. Keberadaan kelembagaan ini menjadi salah satu bagian penting di dalam suatu pengembangan ataupun menjalankan roda pembangunan dan dapat menimbulkan berbagai manfaat positif yang secara langsung dapat dirasakan oleh masyarakat dari keberadaan suatu kelembagaan. Penyusunan model kelembagaan petani kelapa sawit swadaya dilakukan untuk menemukan elemen kunci dari relasi fungsional dengan memperhatikan elemen kunci menggunakan teknik Intepretative Structure Modelling (ISM) dalam menyusun inovasi kelembagaan melalui perancangan struktur kelembagaan untuk kebijakan strategis secara deskriptif. Pendekatan teknik Interpretative Structure Modelling (ISM) dibagi menjadi dua bagian yaitu penyusunan hirarki dan klasifikasi subelemen, melalui prinsip dasar identifikasi struktur yang menggambarkan pengaturan terhadap elemenelemen kunci yanng diuraikan menjadi sejumlah sub-elemen (Suharjito dan Marimin, 2012). Saxena et al. (1992) menjelaskan proses penyusunan hirarki dengan penjenjangan struktur yang dibagi menjadi elemen-elemen dan sejumlah sub-elemen, selanjutnya hubungan antar sub-elemen dinilai berdasarkan perbandingan berpasangan dalam bentuk hubungan konseptual pada Structural SelfInteraction Matrix (SSIM) yang kemudian ditransformasikan dalam bentuk matrik bilangan biner pada tabel Reachability Matrix (RM). Sehingga dapat diketahui nilai driver power (DP) dengan menjumlahkan nilai sub-elemen secara horizontal dan nilai dependence (D) dengan menjumlahkan sub-elemen secara vertikal.

Elemen-elemen kunci dalam program kelembagaan berdasarkan pada penjenjangan struktur oleh Saxena et al. (1992) terbagi menjadi sembilan elemen, yaitu: 1) tujuan dari program; 2) kebutuhan dari program; 3) kendalautama program; 4) tolok ukur untuk menilai setiap tujuan; 5) lembaga yang terlibat dalam pelaksanaan program; 6) sektor masyarakat yang terpengaruhi; 7) perubahan yang dimungkinkan; 8) aktivitas yang dibutuhkan untuk perancangan tindakan; dan 9) ukuran aktivitas guna mengevaluasi hasil yang dicapai olehsetiap aktivitas. Berdasarkan pada sembilan elemen-elemen kunci untuk program kelembagaan tersebut, diketahui bahwa empat elemen utama yang berpengaruh adalah elemen kebutuhan, kendala, tujuan, dan pelaku. Sedangkan, lima elemen lainnya telah terwakilkan ke dalam empat elemen tersebut, seperti elemen tolok ukur tujuan yang dapat direduksi ke dalam elemen tujuan. Dari elemen terpilih tersebut, setiap elemen dariprogram yang dikaji digambarkan menjadi sejumlah sub-elemen, kemudianditetapkan hubungan kontekstual antar sub-elemen dengan menggunakan simbol-simbol berupa huruf $\mathrm{V}, \mathrm{A}, \mathrm{X}$, dan $\mathrm{O}$ yang hubungannya dijelaskan pada Tabel 2.

Marimin (2004) menyatakan bahwa klasifikasi sub-elemen dengan teknik ISM digolongkan ke dalam empat sector. Sektor I (Weak driver-weak dependent variables (autonomous)) dengan nilai $\mathrm{DP}<0,5 \mathrm{X}$ nilai $\mathrm{D}<0,5 \mathrm{X}$, sektor II (Weak driver-strongly dependent variables (dependent)) dengan nilai DP $<0,5 \mathrm{X} \mathrm{D}>0,5 \mathrm{X}$, sektor III (Strong driver-strongly dependent variables (linkage)) dengan nilai DP > 0,5 X dan nilai D > 0,5 X, dan sektor IV (Strong driver-weak dependent variables (independent)) dengan nilai DP $>0,5 \mathrm{X}$ dan nilai $\mathrm{D}<0,5 \mathrm{X}$ dengan nilai $\mathrm{X}$ menyatakan jumlah sub-elemen. 
Tabel 2. Defenisi dari simbol dalam penilaian elemen kelembagaan

\begin{tabular}{|c|c|c|}
\hline $\begin{array}{c}\text { Simbol } \\
\text { penilaian }\end{array}$ & Definisi hubungan kontekstual antar sub-elemen & SSIM \\
\hline $\mathrm{V}$ & $\begin{array}{l}\text { Apabila sub-elemen ke-i mempunyai hubungan kontekstual } \\
\text { terhadap sub-elemen ke-j, namun sub-elemen ke-j tidak } \\
\text { mempunyai hubungan kontekstual terhadap sub-elemen ke-i }\end{array}$ & eij $=1$ dan eji $=0$ \\
\hline A & $\begin{array}{l}\text { Apabila sub-elemen ke-i tidak mempunyai hubungan } \\
\text { kontekstual terhadap sub-elemen ke-j, namun sub-elemen ke-j } \\
\text { mempunyai hubungan kontekstual terhadap sub-elemen ke-i }\end{array}$ & eij $=0$ dan eji $=1$ \\
\hline $\mathrm{X}$ & $\begin{array}{l}\text { Apabila sub-elemen ke-i mempunyai hubungan kontekstual } \\
\text { timbal balik dengan sub-elemen ke-j }\end{array}$ & eij $=1$ dan eji $=1$ \\
\hline $\mathrm{O}$ & $\begin{array}{l}\text { Apabila sub-elemen ke-i tidak mempunyai hubungan } \\
\text { kontekstual timbal balik dengan sub-elemen ke-j }\end{array}$ & eij $=0$ dan eji $=0$ \\
\hline
\end{tabular}

Analisis matriks dari klasifikasi sub-elemen dapat dilihat pada Gambar 2. Secara garis besar, klasifikasi sub-elemen yang digolongkan tersebut memiliki arti sebagai berikut:

Sektor 1 Weak driver-weak dependent variables (autonomous), sub-elemen yang masuk ke dalam sektor ini umunya tidak berkaitan dengan sistem danmungkin mempunyai hubungan sedikit, meskipunh ubungan tersebut bisa saja kuat.

Sektor II Weak driver-strongly dependent variables (dependent), pada sektor ini umumnya peubah tidak bebas.

Sektor III Strong driver-strongly dependent variables (linkage), peubah pada sektor ini harus dikaji secara hati-hati karena hubungan antar peubah tidak stabil. Setiap tindakan pada peubah tersebut memberikan dampak terhadap peubah yang lainnya dan umpan balik pengaruhnya memperbesar dampak.

Sektor IV Strong driver-weak dependent variables (independent), pada sektor ini peubah merupakan bagian sisa dari sistem yang selanjutnya disebut peubah bebas.

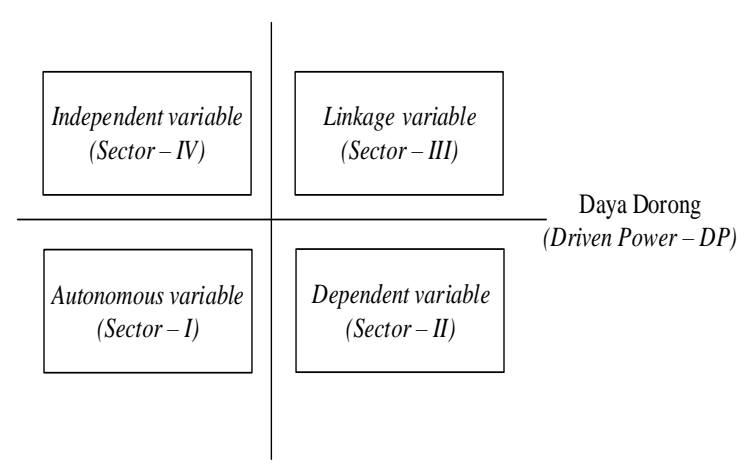

Ketergantungan

(Dependence-D)

Gambar 2. Matriks klasifikasi sub-elemen (Marimin, 2004)

\section{Model Posisi Dayasaing Petani Kelapa Sawit Swadaya}

Posisi dayasaing petani kelapa sawit swadaya dapat diidentifikasi melalui penilaian secara deskriptif. Berdasarkan indikator-indikator dalam model Diamond Porter antara lain (1) strategi, struktur dan persaingan yang memiliki peran dalam penciptaan strategi dalam upaya peningkatan efisiensi dan pembeda, (2) kondisi permintaan yang mendorong pelaku untuk meningkatkan kualitas guna memenuhi keinginan konsumen, (3) kondisi faktor produksi atau sumber daya yang dimiliki meliputi sumber daya alam, sumber daya manusia, modal, infrastruktur fisik, infrastruktur ekonomi, infrastruktur ilmu pengetahuan, dan lain sebagainya. Indikator ke empat (4) yaitu industri pendukung dan industri terkait yang mendukung dalam penyediaan input dan jasa, transaksi, pembagian teknologi, informasi, dan kemampuan tertentu untuk terciptanya produktivitas yang meningkat, sedangkan, peluang yang berada di luar kendali dan pemerintah yang berperan dalam pembentukan kebijakan merupakan dua indikator yang mempengaruhi keempat determinan, tetapi bukan determinan itu sendiri. Keenam indikator tersebut membentuk suatu sistem yang membedakan suatu lokasi dengan lokasi lainnya serta menjelaskan kondisi keunggulan komparatif dari lokasi tersebut dibandingkan dengan kondisi pada lokasi yang lain (Purwaningsih, 2003).

Dalam penelitian penentuan dayasaing petani swadaya kelapa sawit ini, selain menggunakan analisis deskriptif dari Diamond Porter, digunakan juga analisis kuantitatif dengan menghitung indeks daya saing berdasarkan pada modifikasi indeks pembangunan dari Badan Perencanaan Pembangunan Nasional (Bappenas) dengan penyesuaian penilaian berdasarkan indikatorindikator dalam model deskriptif hasil Diamond Porter. Modifikasi perhitungan indeks daya saing dilakukan dengan mengubah rumus, dimensi, dan indikator kuantitatif sehingga dihasilkan indeks komposit melalui penjumlahan secara tertimbang dan menunjukkan dimensi dan indikator yang perlu ditingkatkan dan atau yang tidak perlu ditingkatkan (Bappenas, 2015a; Bappenas, 2015b). Penilaian 
terhadap dimensi dan indikator dilakukan dengan penggunaan skala ordinal melalui metode pairwase comparison yang menggambarkan hubungan relatif antar elemen secara berpasangan dengan perbandingan terhadap intensitas tingkat kepentingannya (Saaty, 2008; Marimin dan Maghfiroh, 2010; Palma-Mendoza et al., 2014). Penentuan prioritas dilakukan berdasarkan pendapat atau opini pakar dengan skala penilaian perbandingan berpasangan seperti dapat dilihat pada Tabel 3.

Tabel 3. Skala penilaian pada perbandingan berpasangan (Saaty, 2008)

\begin{tabular}{cl}
\hline Nilai Intensitas & \multicolumn{2}{l}{ Defenisi } \\
\hline 1 & $\begin{array}{l}\text { A sama penting dengan B } \\
\text { A sedikit lebih penting } \\
\text { daripada B }\end{array}$ \\
5 & $\begin{array}{l}\text { A jelas lebih penting } \\
\text { daripada B } \\
\text { A sangat jelas lebih penting } \\
\text { daripada B } \\
\text { A mutlak lebih penting } \\
\text { daripada B } \\
\text { Jika nilai kepentingan berada } \\
\text { antara dua perbandingan } \\
\text { berdekatan }\end{array}$ \\
\hline
\end{tabular}

Hasil penilaian pairwase comparison tersebut menjadi input dalam penghitungan indeks kinerja yang akan dikalikan dengan masing-masing skor indikatornya dan konstanta indikator secara akumulatif. Pengukuran indeks daya saing ini diformulasikan sebagai berikut:

$$
\mathrm{IDS}=\left(\sum_{i}^{n} B i x \operatorname{Vi} x \mathrm{Ki}\right)
$$

Keterangan :

IDS : Indeks Daya Saing

Bi : Bobot indikator ke-i

Vi : Skor indikator ke-i (skala Likert)
Ki : Konstanta indikator ke-i (100/jumlah rentang skala ordinal ke-i)

Skor indikator pada penilaian indeks daya saing menggunakan skala Likert dengan skala ordinal untuk menentukan tingkat daya saing dari masing-masing indikator yang telah ditetapkan. Konstanta indikator pada penilaian indeks daya saing ini merupakan suatu modifikasi yang diberlakukan karena diperlukannya penyesuaian terhadap rentang skala ordinal indikator yang tidak seragam, sedangkan pada indeks pembangunan keseluruhan indikator memiliki skala ordinal seragam dari 1 hingga 5 sehingga langsung dikalikan dengan konstanta tetap yang diperoleh dari hasil bagi nilai 100 dengan jumlah rentang skala ordinal pada tiap indikator. Berdasarkan hasil perhitungan indeks daya saing maka akan dihasilkan nilai yang dapat diklasifikasikan kedalam tiga kategori yang disesuaikan untuk penelitian, antara lain kelompok petani swadaya tertinggal (indeks daya saing $\leq 50$ ), kelompok petani swadaya berkembang $(50<$ indeks daya saing $\leq 75$ ), dan kelompok petani swadaya mandiri (indeks daya saing > 75).

\section{HASIL DAN PEMBAHASAN}

\section{Analisis Kebutuhan}

Analisis kebutuhan dilakukan sebagai langkah awal dalam pengkajian terhadap sebuah sistem secara menyeluruh, dilakukan melalui identifikasi pihak-pihak yang terlibat secara langsung ataupun tidak langsung di dalam terbentuknya model pemetaan wilayah potensial pengembangan hilirisasi kelapa sawit berdasarkan daya saing dan kelembagaan petani swadaya. Mengacu pada Rencana Induk Pembangunan Industri Nasional 2015-2035 (RIPIN) (Kemenperin, 2015) dan beberapa kondisi tantangan hilirisasi kelapa sawit, analisis kebutuhan untuk model dalam penelitian ini dapat dilihat pada Tabel 4.

Tabel 4. Analisis kebutuhan pemetaan wilayah hilirisasi kelapa sawit

\begin{tabular}{|c|c|c|}
\hline No & Pihak & Kebutuhan \\
\hline 1 & Petani swadaya & $\begin{array}{l}\text { a. Meningkatnya produktivitas tanaman kelapa sawit } \\
\text { b. Kemudahan memperoleh pembiayaan/modal } \\
\text { c. Efisiensi biaya produksi } \\
\text { d. Peningkatan pendapatan } \\
\text { e. Terjaminnya pemasaran kelapa sawit } \\
\text { f. Kepastian terhadap harga }\end{array}$ \\
\hline 2 & Pemerintah daerah & $\begin{array}{l}\text { a. Peningkatan ekonomi daerah } \\
\text { b. Peningkatan lapangan kerja dan kesempatan usaha } \\
\text { c. Menciptakan iklim industri kecil menengah untuk menciptakan daerah } \\
\text { mandiri sentra pengolahan kelapa sawit }\end{array}$ \\
\hline 3 & Pemerintah pusat & $\begin{array}{l}\text { d. Kemajuan dalam infrastuktur, sarana, dan prasarana } \\
\text { a. Implementasi program peremajaan kelapa sawit } \\
\text { b. Pembangunan wilayah pusat perwilayahan industri } \\
\text { c. Pembangunan sumber daya untuk industri prioritas } \\
\text { d. Peningkatan daya saing kelapa sawit petani swadaya } \\
\text { e. Peningkatan proses produksi dan penggunaan produk di dalam negeri }\end{array}$ \\
\hline
\end{tabular}




\section{Identifikasi Sistem}

Identifikasi sistem dalam penelitian ini bertujuan sebagai tahapan yang digunakan dalam pengenalan terhadap kebutuhan sistem untuk menggambarkan suatu rantai hubungan antara penyataan dari kebutuhan-kebutuhan khusus dalam pendefenisian masalah yang harus diselesaikan untuk mencukupi kebutuhan yang dijabarkan dalam bentuk diagram lingkar sebab akibat dan diagram input output. Diagram lingkar sebab akibat menggambarkan suatu keterhubungan antar elemen penyusun sistem yang diturunkan berdasarkan pada analisis kebutuhan sistem, hubungan antar elemen dalam diagram lingkar sebab akibat dapat bersifat positif ataupun negatif maupun timbal balik ataupun searah. Hasil identifikasi awal terhadap diagram lingkar sebab akibat sistem dalam model pemetaan wilayah pengembangan hilirisasi kelapa sawit dapat dilihat pada Gambar 3 .

Diagram input output menggambarkan skema identifikasi yang didasarkan pada masukan dan keluaran dari model yang dikembangkan dengan dilengkapi proses operasi berupa input dan output yang terkendali dan tidak terkendali. Hasil identifikasi diagram input output model pemetaan wilayah potensial pengembangan hilirisasi kelapa sawit dapat dilihat pada Gambar 4.

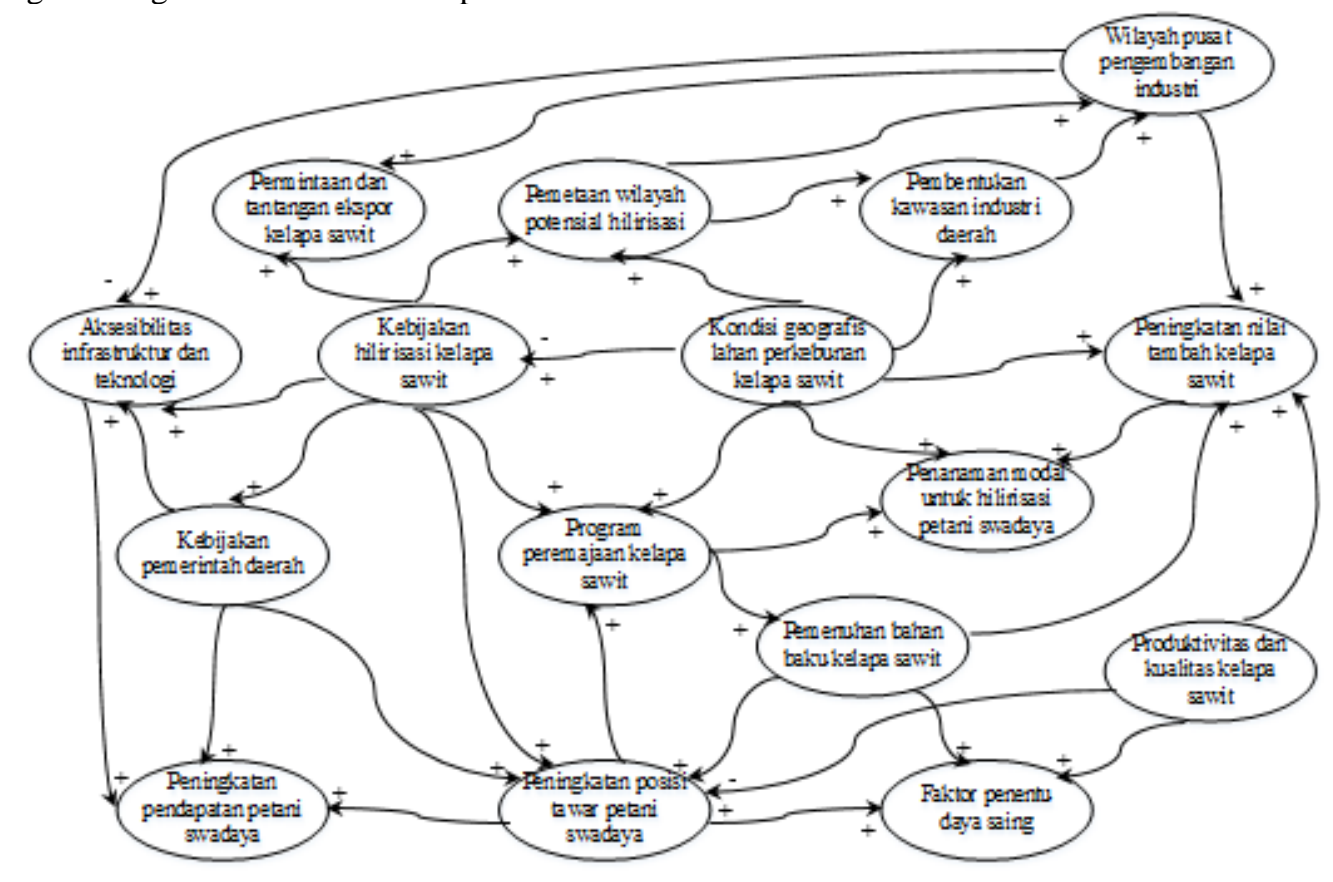

Keterangan:

$+\quad$ : Perbaikan terhadap faktor lainnya

- $\quad$ : Penurunan terhadap faktor lainnya

Gambar 3. Diagram lingkar sebab akibat

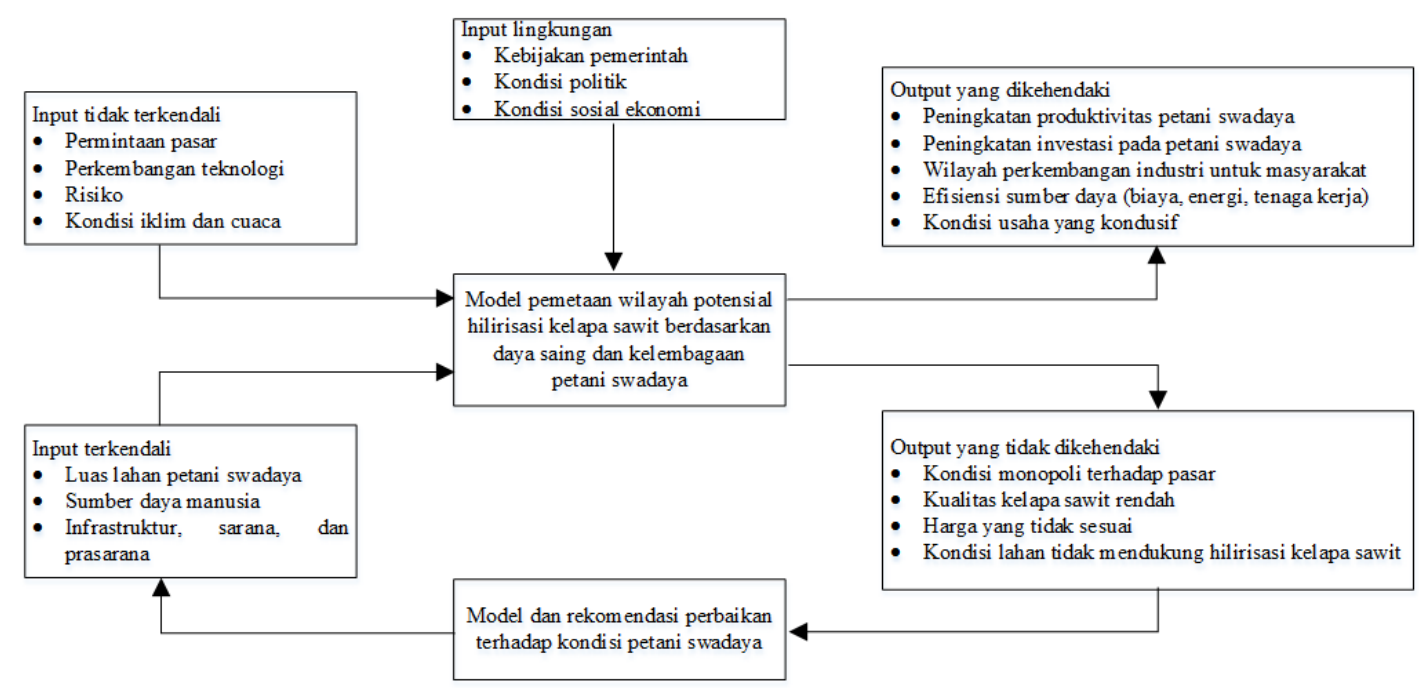

Gambar 4. Diagram input output 


\section{Model Pemetaan Wilayah Potensial Hilirisasi Kelapa Sawit}

Model pemetaan wilayah potensial untuk hilirisasi kelapa sawit ini dilakukan melalui analisis situasional terlebih dahulu untuk mengetahui sebaran petani swadaya sehingga kondisi lahan untuk analisis spasial yang diamati akan berada pada daerah dengan sebaran petani rakyat tertinggi. Tingginya jumlah petani swadaya dalam suatu daerah menunjukkan bahwa tingkat perkebunan untuk pembuatan model akan lebih presisi mendekati kondisi nyata di lapangan. Selain itu, tingginya jumlah petani swadaya menunjukkan bahwa potensi perkebunan kelapa sawit petani swadaya untuk hilirisasi kelapa sawit juga sangat berpotensi. Berdasarkan pada data luasan lahan perkebunan kelapa sawit (Dirjenbun, 2017), diketahui bahwa Provinsi Riau memiliki luas lahan tertinggi sejumlah 1.637.775 hektar dengan total jumlah petani swadaya sebanyak 522.722 kepala keluarga dengan sebaran petani swadaya seperti pada Tabel 5.

Tabel 5. Sebaran petani swadaya di Provinsi Riau

\begin{tabular}{lc}
\hline \multicolumn{1}{c}{ Kabupaten } & Jumlah Petani (KK) \\
\hline Kab Kampar & 86.307 \\
Kab Rokan Hulu & 69.323 \\
Kab Pelalawan & 40.115 \\
Kab Indragiri Hulu & 31.209 \\
Kab Kuantan Sengingi & 42.682 \\
Kab Bengkalis & 36.871 \\
Kab Rokan Hilir & 61.635 \\
Kab Dumai & 10.241 \\
Kab Siak & 64.326 \\
Kab Indragiri Hilir & 79.309 \\
Kab Pakanbaru & 704 \\
Kab Kepulauan Meranti & - \\
\hline \multicolumn{2}{c}{ Total } \\
\hline \multicolumn{2}{c}{$\mathbf{5 2 2 . 7 2 2}$} \\
\hline
\end{tabular}

Berdasarkan pada data sebaran petani swadaya tersebut, diketahui bahwa jumlah petani terbesar berturut-turut berada pada Kabupaten Kampar, Kabupaten Indragiri Hilir, dan Kabupaten Rokan Hulu. Besarnya jumlah sebaran petani swadaya kelapa sawit di Provinsi Riau ini menjadikan daerah tersebut menjadi lokasi potensial untuk pengembangan dan hilirisasi kelapa sawit. Selain itu, hal ini didukung dengan rencana pemerintah yang tertuang dalam RIPIN (Kemenperin, 2015) bahwa aspek-aspek yang perlu diperhatikan dalam karakterisasi dan relevansi untuk pembangunan industri nasional melalui penyiapan standarisasi dan infrastruktur industri termasuk perwilayahan industri yang disebut sebagai Wilayah Pusat Pertumbuhan Industri (WPPI), sehingga pendekatan spasial untuk pemetaan wilayah potensial pengembangan hilirisasi kelapa sawit untuk industri kecil menengah bagi petani swadaya.
Diketahui, bahwa komoditi perkebunan kelapa sawit di Kabupaten Kampar merupakan salah satu pendapatan utama masyarakat karena memiliki nilai ekonomi tinggi dan mudah dibudidayakan Luas tanam kelapa sawit terbesar terdapat di Kecamatan Tapung, dengan tingkat produksi tertinggi. Berdasarkan pada lahan perkebunan di Kabupaten Tapung, dimiliki oleh masyarakat, perkebunan negara, dan perkebunan swasta. Perkebunan kelapa sawit petani swadaya di Kecamatan Tapung seluas 13.290,126 hektar dari luas total perkebunan kelapa sawit 457.133,351 hektar. Permasalahan pada perkebunan kelapa sawit diketahui terjadi pada perkebunan rakyat karena praktik yang kurang sesuai. Sehingga, berdasarkan pada hal tersebut maka dilakukan proses pemetaan dengan bantuan aplikasi sistem informasi geografis untuk membangun suatu model spasial penentuan tingkat potensial perkebunan kelapa sawit petani swadaya.

Pembangunan model spasial untuk pemetaan tingkat potensial perkebunan kelapa sawit petani swadaya ini ditunjukkan melalui data spasial dalam bentuk titik, garis, dan sudut, serta disimpan dalam bentuk raster dan vector pada peta citra satelit perkebunan kelapa sawit yang dapat digunakan untuk membuat pemodelan dan analisis sebagai dasar untuk pengambilan keputusan yang lebih baik dan akurat yang dalam jangka panjang akan berpengaruh terhadap efisiensi informasi (Suroso et al., 2004). Penerapan sistem informasi geografis untuk pemetaan perkebunan kelapa sawit petani swadaya ini diharapkan mampu menjadi media yang efektif dalam rangka memberikan informasi mengenai perkebunan kelapa sawit serta memberikan gambaran mengenai persebaran komoditas perkebunan kelapa sawit petani swadaya. Selain itu juga diharapkan dapat dijadikan bahan pertimbangan dalam mengambil langkah kebijakan pengembangan hilirisasi kelapa sawit dalam rangka pengembangan dan peningkatan produksi komoditas perkebunan petani swadaya.

Pemetaan tingkat potensial wilayah perkebunan kelapa sawit swadaya dilakukan melalui proses pembuatan model spasial dengan melihat masing-masing indikator yang berpengaruh terhadap produktivitas dan keberlanjutan perkebunan kelapa sawit milik petani swadaya. Indikator yang dipilih dalam menentukan tingkat potensial wilayah perkebunan kelapa sawit petani swadaya ini didasarkan pada pengaruh faktor manusia dan faktor lingkungan. Berdasarkan pada kondisi tersebut maka dapat diketahui kesesuaiannya. Pembuatan model spasial menggunakan layer jaringan jalan, layer jaringan sungai, dan layer lokasi pemukiman sebagai indikator yang mempengaruhi dari faktor atau kriteria manusia; sedangkan layer jenis tanah dan layer kemiringan lahan merupakan faktor atau kriteria lingkungan yang mempengaruhi tingkat potensial kelapa sawit petani swadaya. 


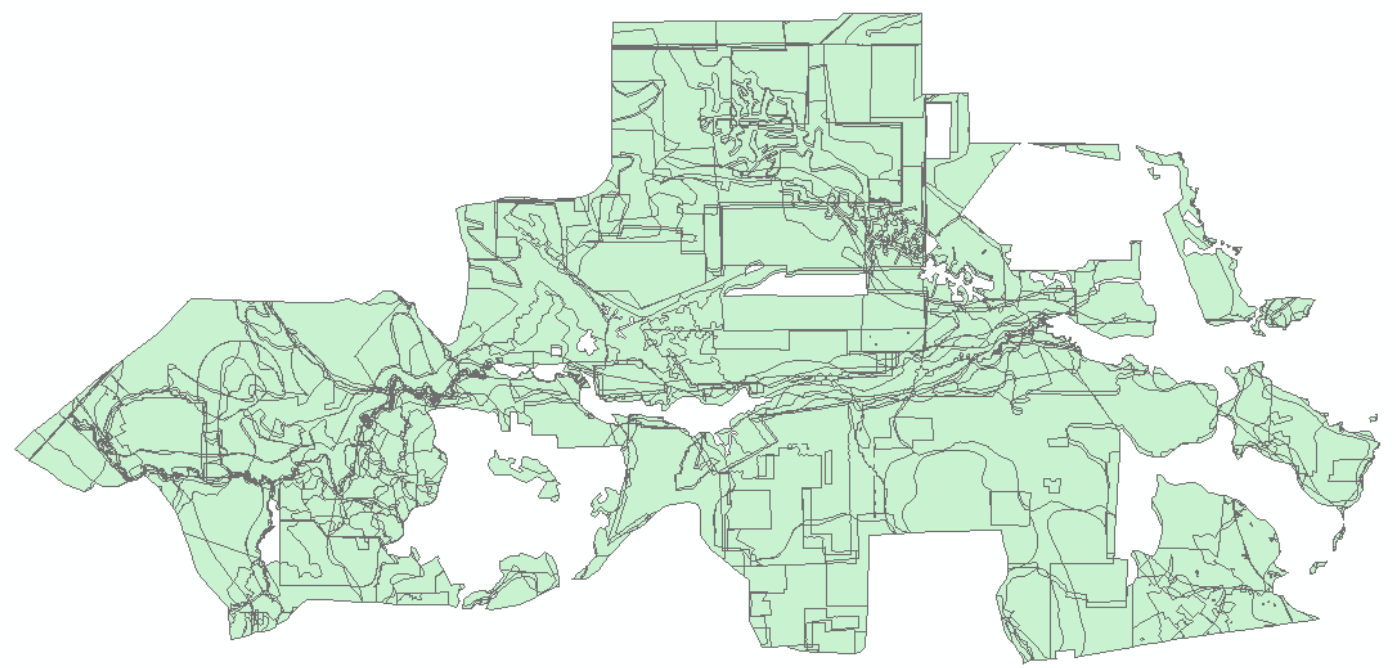

Gambar 5. Perkebunan kelapa sawit di Kecamatan Tapung

Tahapan pemrosesan data dilakukan dengan proyeksi grid UTM (Universal Transverse Mercator) dengan datum WGS (World Geodetic System) 1984 zona 47 N untuk Kecamatan Tapung, Provinsi Riau seperti pada Gambar 5 untuk menyeleksi perkebunan kelapa sawit petani swadaya dari keseluruhan perkebunan kelapa sawit.

Berdasarkan pada proses pembobotan untuk masing-masing indikator dalam kriteria lingkungan dan kriteria manusia, maka dihasilkan persamaan matematis seperti berikut:

$$
\begin{aligned}
\mathrm{Xi}= & 0,355(0,808 \mathrm{KJT}+0,192 \mathrm{KK})+0,645(0,419 \\
& \mathrm{JJ}+0,274 \mathrm{JS}+0,306 \mathrm{JP})
\end{aligned}
$$

$$
\mathrm{Xi}=\underset{\mathbf{0 , 3 0 6} \mathrm{JP}}{\mathbf{0 , 2 8 7} \mathrm{JT}}+\mathbf{0 , 0 6 8} \mathrm{KL}+\mathbf{0 , 2 7 1} \mathrm{JJ}+\mathbf{0 , 1 7 7} \mathrm{JS}+
$$

Keterangan:

JT = Jenis tanah

$\mathrm{KL}=$ Kemiringan lereng

$\mathrm{JJ}=$ Jarak terhadap jaringan jalan

JS = Jarak terhadap jaringan sungai

JP = Jarak terhadap lokasi pemukiman

Persamaan matematis yang telah dihasilkan untuk pemodelan klasifikasi tingkat potensial perkebunan kelapa sawit petani swadaya digunakan untuk memperoleh nilai skor total dari seluruh indikator yang mempengaruhi tingkat potensial perkebunan kelapa sawit petani swadaya. Berdasarkan hasil perhitungan untuk total skor, diperoleh nilai maksimum 4,067 dan nilai minimum 1,601. Berdasarkan nilai tersebut, klasifikasi untuk penentuan tingkat potensial perkebunan kelapa sawit petani swadaya dibuat dalam tiga kelas menggunakan rumus klasifikasi seperti berikut:

$$
\begin{aligned}
\text { Selang klasifikasi } & =\quad \begin{array}{l}
\text { (nilai maksimum }- \\
\text { nilai minimum }) / 3
\end{array} \\
& =\quad(4,067-1,601) / 3 \\
& =0,822
\end{aligned}
$$

Selanjutnya, dilakukan klasifikasi pada tiga kelas tersebut dengan interval selang seperti pada Tabel 6 dengan penamaan kelas terdiri atas perkebunan kelapa sawit tidak potensial, berkembang, dan potensial.

Tabel 6. 6Klasifikasi tingkat potensial perkebunan kelapa sawit

\begin{tabular}{cl}
\hline Selang nilai & \multicolumn{1}{c}{ Klasifikasi } \\
\hline $1,601-2,423$ & $\begin{array}{l}\text { Perkebunan kelapa sawit } \\
\text { tidak potensial }\end{array}$ \\
$>2,423-3,245$ & $\begin{array}{l}\text { Perkebunan kelapa sawit } \\
\text { berkembang }\end{array}$ \\
$>3,245$ & $\begin{array}{l}\text { Perkebunan kelapa sawit } \\
\text { potensial }\end{array}$ \\
\hline
\end{tabular}

Hasil klasifikasi berdasarkan pada selang nilai tersebut, menghasilkan klasifikasi seperti pada Tabel 7. Berdasarkan pada persamaan model spasial yang dihasilkan, perkebunan kelapa sawit petani swadaya di Kecamatan Tapung tahun 2016 memiliki nilai dalam kelas potensial dengan luas lahan terbesar, yaitu seluas 9.262,8 hektar. Berdasarkan hasil klasifikasi yang telah diperoleh untuk perkebunan kelapa sawit petani swadaya di Kecamatan Tapung tahun 2016 tersebut, maka wilayah perkebunan kelapa sawit petani swadaya yang berada dalam kondisi berkembang dan tidak potensial mungkin untuk ditingkatkan dan perlu untuk menjadi perhatian bagi pihak pengambil keputusan agar perkebunan tersebut dapat menjadi lebih baik. 
Tabel 7. Luas lahan tingkat potensial perkebunan kelapa sawit petani swadaya

\begin{tabular}{lc}
\hline \multicolumn{1}{c}{ Klasifikasi } & Luas (ha) \\
\hline Tidak Potensial & 37,956 \\
Berkembang & $3.989,384$ \\
Potensial & $9.262,8$ \\
\hline
\end{tabular}

\section{Model Kelembagaan Petani Swadaya Kelapa Sawit}

Penyusunan model kelembagaan petani swadaya kelapa sawit untuk mendukung hilirisasi kelapa sawit dilakukan melalui strukturisasi sistem kelembagaan yang melingkupi empat elemen kajian, antara lain tujuan, kendala, kebutuhan, dan pelaku yang diharapkan dapat menghasilkan rekomendasi untuk kebijakan strategis hilirisasi. Masing-masing elemen dalam penyusunan model kelembagaan petani swadaya terdiri atas sub-sub elemen berturutturut seperti pada Tabel 8 untuk elemen kebutuhan, Tabel 9 untuk elemen kendala, Tabel 10 untuk elemen tujuan, dan Tabel 11 untuk elemen pelaku. Berdasarkan pada masing-masing sub-elemen, dapat diperoleh hubungan kontekstualnya yang mewakili tipe hubungan antara dua elemen sistem sehingga dapat dirumuskan strategi perbaikannya.

Tabel 8. Sub-elemen dari elemen kebutuhan

\begin{tabular}{|c|c|}
\hline No & Sub-elemen kebutuhan \\
\hline 1 & $\begin{array}{l}\text { Peningkatan nilai tambah hasil produksi } \\
\text { kelapa sawit petani swadaya }\end{array}$ \\
\hline 2 & $\begin{array}{l}\text { Ketersediaan benih tersertifikasi untuk } \\
\text { petani kelapa sawit swadaya }\end{array}$ \\
\hline 3 & $\begin{array}{l}\text { Ketersediaan dan kelancaran akses modal } \\
\text { dan fasilitas kredit petani swadaya }\end{array}$ \\
\hline 4 & $\begin{array}{l}\text { Ketersediaan infrastruktur dan teknologi } \\
\text { untuk petani swadaya kelapa sawit }\end{array}$ \\
\hline 5 & $\begin{array}{l}\text { Perjanjian kontrak kerja sama petani } \\
\text { swadaya dengan lembaga terkait }\end{array}$ \\
\hline 6 & $\begin{array}{l}\text { Dukungan kebijakan pemerintah pusat dan } \\
\text { pemerintah daerah terhadap petani swadaya }\end{array}$ \\
\hline 7 & $\begin{array}{l}\text { Sosialisasi program pengembangan industri } \\
\text { kecil menengah hilirisasi kelapa sawit pada } \\
\text { petani swadaya dan stakeholder terkait }\end{array}$ \\
\hline 8 & $\begin{array}{l}\text { Sistem pendanaan yang mendorong investasi } \\
\text { stakeholder terkait untuk petani swadaya }\end{array}$ \\
\hline 9 & $\begin{array}{l}\text { Penyiapan sumber daya manusia di bagian } \\
\text { hulu kelapa sawit untuk mendukung } \\
\text { hilirisasi kelapa sawit }\end{array}$ \\
\hline 10 & $\begin{array}{l}\text { Penyiapan sumber daya manusia untuk } \\
\text { program hilirisasi kelapa sawit }\end{array}$ \\
\hline 11 & $\begin{array}{l}\text { Peningkatan insentif untuk produktivitas } \\
\text { hasil produksi petani swadaya }\end{array}$ \\
\hline 12 & $\begin{array}{l}\text { Jaminan pasar dan kestabilan harga untuk } \\
\text { petani swadaya kelapa sawit }\end{array}$ \\
\hline 13 & $\begin{array}{l}\text { Pemetaan potensi petani swadaya dalam } \\
\text { mendukung pengembangan sumber daya } \\
\text { industri dan hilirisasi kelapa sawit }\end{array}$ \\
\hline
\end{tabular}

Tabel 9. Sub-elemen dari elemen kendala

\begin{tabular}{|c|c|}
\hline No & Sub-elemen kendala \\
\hline 1 & $\begin{array}{l}\text { Ketidaktersediaan lembaga pendukung } \\
\text { sebagai wadah bagi petani swadaya }\end{array}$ \\
\hline 2 & $\begin{array}{l}\text { Produktivitas kelapa sawit petani swadaya } \\
\text { cukup rendah }\end{array}$ \\
\hline 3 & $\begin{array}{l}\text { Belum jelasnya perundang-undangan } \\
\text { untuk kontribusi petani swadaya dalam } \\
\text { pengembangan hilirisasi kelapa sawit }\end{array}$ \\
\hline 4 & Hambatan perdagangan internasional \\
\hline 5 & $\begin{array}{l}\text { Keterbatasan terhadap ketersediaan } \\
\text { infrastuktur dan teknologi }\end{array}$ \\
\hline 6 & $\begin{array}{l}\text { Ketidakpercayaan petani } \\
\text { terhadap program pemerintah }\end{array}$ \\
\hline 7 & $\begin{array}{l}\text { Kurangnya integrasi pelaku sepanjang } \\
\text { rantai nilai kelapa sawit }\end{array}$ \\
\hline 8 & $\begin{array}{l}\text { Kualitas tenaga kerja rendah dalam } \\
\text { penguasaan teknologi }\end{array}$ \\
\hline 9 & $\begin{array}{l}\text { Kurang bersaing dengan kelapa sawit } \\
\text { milik perusahaan pemerintah/swasta }\end{array}$ \\
\hline 10 & $\begin{array}{l}\text { Hambatan kelembagaan terkait perijinan, } \\
\text { birokrasi, dan hal lainnya }\end{array}$ \\
\hline 11 & $\begin{array}{l}\text { Tidak adanya jaminan keberlangsungan } \\
\text { terhadap program hilirisasi kelapa sawit }\end{array}$ \\
\hline
\end{tabular}

Tabel 10. Sub-elemen dari elemen tujuan

\begin{tabular}{|c|c|}
\hline No & Sub-elemen tujuan \\
\hline 1 & $\begin{array}{l}\text { Jaminan harga dan pasar terhadap petani } \\
\text { kelapa sawit }\end{array}$ \\
\hline 2 & $\begin{array}{l}\text { Meningkatkan kepercayaan dan kontribusi } \\
\text { petani swadaya dalam mendukung } \\
\text { hilirisasi kelapa sawit }\end{array}$ \\
\hline 3 & $\begin{array}{l}\text { Peningkatan motivasi petani untuk } \\
\text { peremajaan kelapa sawit }\end{array}$ \\
\hline 4 & $\begin{array}{l}\text { Pemenuhan kebutuhan sumber daya secara } \\
\text { efisien, ramah lingkungan, dan } \\
\text { berkelanjutan }\end{array}$ \\
\hline 5 & $\begin{array}{l}\text { Pewujudan kemandirian nasional dan } \\
\text { peningkatan sektor ekonomi rakyat }\end{array}$ \\
\hline 6 & $\begin{array}{l}\text { Memiliki nilai tambah progresif di dalam } \\
\text { negeri sehingga berdaya saing } \\
\text { internasional }\end{array}$ \\
\hline 7 & $\begin{array}{l}\text { Memiliki keunggulan } \\
\text { penguasaan bahan baku, dan teknologi } \\
\text { produksi }\end{array}$ \\
\hline 8 & $\begin{array}{l}\text { Meningkatkan kuantitas dan kualitas } \\
\text { penyerapan tenaga kerja dari petani } \\
\text { swadaya }\end{array}$ \\
\hline 9 & $\begin{array}{l}\text { Mendorong penyebaran dan pemerataan } \\
\text { industri }\end{array}$ \\
\hline 10 & $\begin{array}{l}\text { Tersedianya data wilayah potensial untuk } \\
\text { pengembangan hilirisasi kelapa sawit }\end{array}$ \\
\hline 11 & $\begin{array}{l}\text { Pembangunan sentra industri kecil dan } \\
\text { menengah }\end{array}$ \\
\hline
\end{tabular}


Tabel11. Sub-elemen dari elemen pelaku

\begin{tabular}{cl}
\hline No & \multicolumn{1}{c}{ Sub-elemen pelaku } \\
\hline 1 & Petani Swadaya Kelapa Sawit \\
2 & Koperasi Petani Swadaya Kelapa Sawit \\
3 & Pemerintah Daerah \\
4 & $\begin{array}{l}\text { Asosiasi Petani Kelapa Sawit Indonesia } \\
\text { (APKASINDO) }\end{array}$ \\
5 & $\begin{array}{l}\text { Gabungan Pengusaha Kelapa Sawit } \\
\text { Indonesia (GAPKI) } \\
6\end{array}$ \\
$\begin{array}{l}\text { Badan Pengelola Dana Perkebunan Kelapa } \\
\text { Sawit (BPDPKS) } \\
7\end{array}$ & $\begin{array}{l}\text { Direktorat Jenderal Agro Kementerian } \\
\text { Perindustrian }\end{array}$ \\
\hline
\end{tabular}

Model Daya Saing Petani Swadaya Kelapa Sawit

Model yang digunakan untuk penilaian daya saing dilakukan dengan analisis deskriptif pada model konseptual Diamond Porter (Porter, 1990). Faktor-faktor yang diperhatikan dalam penentuan daya saing terdiri atas enam indikator yang didekomposisi menjadi masing-masing variabelnya seperti pada Tabel 12. Berdasarkan pada variabelvariabel tersebut, maka penentuan daya saing dari petani swadaya dapat diketahui bahwa variabel tersebut mempengaruhi posisi, kinerja, serta tantangan petani swadaya daya kelapa sawit dalam pemetaan wilayah potensial dan hilirisasi kelapa sawit secara terintegrasi.

Tabel 12. Variabel-variabel dalam indikator daya saing model konseptual Diamond Porter

\begin{tabular}{|c|c|}
\hline Indikator Diamond Porter & Variabel \\
\hline $\begin{array}{l}\text { Strategi, struktur dan } \\
\text { persaingan }\end{array}$ & $\begin{array}{l}\text { Aksesibilitas jalan/lalu lintas dan transportasi } \\
\text { Jaringan pemasaran secara internal } \\
\text { Upaya peningkatan efisiensi dan pembeda } \\
\text { Strategi fungsional keuangan } \\
\text { Strategi fungsional produksi } \\
\text { Strategi korporasi kebijakan pemerintah } \\
\text { Strategi bisnis perbaikan posisi daya saing } \\
\text { Strategi pemasaran (negosiasi harga) }\end{array}$ \\
\hline Kondisi permintaan & $\begin{array}{l}\text { Sumber permintaan / Pangsa pasar } \\
\text { Jumlah permintaan } \\
\text { Pola permintaan } \\
\text { Pertumbuhan permintaan } \\
\text { Informasi pasar terkait trend perubahan }\end{array}$ \\
\hline $\begin{array}{l}\text { Kondisi faktor produksi atau } \\
\text { sumber daya yang dimiliki }\end{array}$ & $\begin{array}{l}\text { Keahlian sumber daya manusia } \\
\text { Produktivitas lahan } \\
\text { Kondisi geografis dan potensi lahan } \\
\text { Aksesibilitas terhadap alat dan mesin perkebunan/pengolahan } \\
\text { Ketersediaan dan kemudahan akses kepada konsumen } \\
\text { Sumber daya ilmu pengetahuan dan teknologi (pusat penelitian terkait) } \\
\text { Biaya-biaya terkait faktor produksi (sumber daya modal) }\end{array}$ \\
\hline $\begin{array}{l}\text { Industri pendukung dan } \\
\text { industri terkait }\end{array}$ & $\begin{array}{l}\text { Teknologi informasi } \\
\text { Ketersediaan jasa } \\
\text { Kemampuan meningkatkan produktivitas } \\
\text { Pengadaan teknologi } \\
\text { Industri kecil menengah } \\
\text { Kualitas } \\
\text { Proses pengadaan } \\
\text { Adanya keterlibatan pemerintah/instansi terkait dalam pendampingan } \\
\text { Kerjasama dengan lembaga penelitian/perguruan tinggi dalam inovasi dan } \\
\text { pengembangan } \\
\text { Adanya keterlibatan pihak pemberi modal dalam pembiayaan petani swadaya }\end{array}$ \\
\hline $\begin{array}{l}\text { Peluang yang berada di luar } \\
\text { kendali }\end{array}$ & $\begin{array}{l}\text { Kondisi politik daerah } \\
\text { Kebijakan yang tidak mendukung petani swadaya } \\
\text { Kondisi alam }\end{array}$ \\
\hline $\begin{array}{l}\text { Pemerintah yang berperan } \\
\text { dalam pembentukan } \\
\text { kebijakan }\end{array}$ & $\begin{array}{l}\text { Upaya peningkatan kesejahteraan penduduk daerah } \\
\text { Kompetisi inti sebagai pembeda } \\
\text { Lapangan pekerjaan dan peningkatan pendapatan } \\
\text { Program peremajaan kelapa sawit } \\
\text { Kebijakan industri kecil } \\
\text { Program fasilitasi } \\
\text { Pelatihan }\end{array}$ \\
\hline
\end{tabular}


Validasi Konseptual

Proses validasi dilakukan untuk pembentukan, evaluasi, pengujian, dan percobaan model untuk memecahkan masalah memadai dan konsisten terhadap penerapan model yang dimaksud (Sargent, 2015). Suatu model dapat digunakan jika telah terbukti valid, validasi yang dilakukan terhadap keseluruhan model konseptual pemetaan wilayah hilirisasi kelapa sawit berdasarkan dayasaing dan kelembagaan petani swadaya dilakukan menggunakan validitas model konseptual dengan teknik face validity. Validitas model konseptual adalah menentukan bahwa (1) teori-teori dan asumsi yang mendasari model konseptual benar, dan (2) representasi model masalah entitas dan struktur model, logika, dan matematika dan hubungan sebabakibat adalah "masuk akal" untuk yang dimaksudkan tujuan dari model. Teknik face validity ini dilakukan melalui proses justifikasi dari model yang telah dibangun kepada pakar untuk kesesuaian logika dari model konseptual (Weiner dan Craighead, 2010; Sargent, 2010). Proses validasi melalui pakar ini dilakukan dengan penilaian subjektif terhadap model yang telah dibangun sesuai dengan keterhubungan antara input dan output dari model.

\section{KESIMPULAN DAN SARAN}

\section{Kesimpulan}

Model konseptual pemetaan wilayah potensial hilirisasi kelapa sawit berdasarkan pada daya saing dan kelembagaan dilakukan untuk membangun suatu model yang menjadi suatu solusi integratif yang secara kompeherensif digunakan untuk mengembangkan hilirisasi kelapa sawit yang difokuskan pada keberadaan petani swadaya kelapa sawit sebagai produsen utama bahan baku untuk proses hilir kelapa sawit. Pemodelan pemetaan wilayah potensial perkebunan kelapa sawit petan swadaya, menghasilkan klasifikasi perkebunan kelapa sawit tidak potensial, berkembang, dan potensial.

Hasil klasifikasi menunjukkan bahwa kondisi perkebunan kelapa sawit berada pada kondisi berkembang. Perumusan model konseptual kelembagaan berdasarkan elemen-elemen kunci terpilih, menunjukkan bahwa masing-masing ada 13 sub-elemen kebutuhan, 11 sub-elemen kendala, 11 sub-elemen tujuan, dan 7 sub-elemen pelaku.S elain itu, pemodelan daya saing berdasarkan pada kerangka Diamond Porterdengan menggunakan 6 indikator. Berdasarkan 6 indikator dalam model konseptual Diamond Porter tersebut, masing-masing dihasilkan 8 variabel untuk indikator strategi, struktur, dan persaingan; 5 variabel untuk indikator kondisi permintaan; 7 variabel untuk indikator kondisi faktor produksi; 10 variabel untuk indikator industri pendukung atau industri terkait; 3variabel untuk indikator peluang yang berada di luar kendali; dan 7 variabel untuk indikator peran pemerintah.
Berdasarkan pada model konseptual terintegrasi tersebut, maka dapat dihasilkan suatu kontribusi strategi atau langkah kebijakan untuk meningkatkan posisi petani swadaya dalam mendukung hilirisasi kelapa sawit.

\section{Saran}

Untuk penyempurnaan penelitian, maka perlu dilakukan serangkaian proses pengembangan model lebih lanjut untuk menghasilkan suatu model dan pengukuran secara kuantitatif dari masingmasing model konseptual yang telah dihasilkan. Selanjutnya, analisis mendalam untuk pemetaan wilayah perkebunan kelapa sawit juga diperlukan dengan penambahan indikator-indikator lain seperti jarak dengan industri pengolahan kelapa sawit dan indikator yang secara langsung berpengaruh pada mutu kelapa sawit.

Sintesis penilaian pakar untuk analisis kuantitatif terhadap model konseptual kelembagaan dan daya saing juga diperlukan sehingga dapat menghasilkan rumusan rekomendasi yang berkontribusi terhadap kondisi petani swadaya kelapa sawit, penerapan langkah implementasi terhadap kondisi nyata di lapangan, dan menentukan langkah strategis untuk meningkatkan posisi petani swadaya dalam mendukung hilirisasi kelapa sawit.

\section{DAFTAR PUSTAKA}

Akmal F, Ramdani F, Pinandito A. 2018. Sistem informasi pengelolaan perkebunan kelapa sawit berbasis web gis. Jurnal Pengembangan Teknologi Informasi dan Ilmu Komputer. 2 (5): 1894-1901.

Alwarritzi, Nanseki, Chomei. 2015. Analysis of the factors influencing the technical efficiency among oil palm smallholder farmers in Indonesia. Proc. Env. Sci. 28: 630-638.

Arifin B. 2005. Ekonomi Kelembangaan Pangan. Jakarta (ID): Pustaka LP3ES Indonesia.

[Bappenas] Badan Perencanaan Pembangunan Nasional. 2015a. Modul Perhitungan Indeks Pembangunan Desa (IPD). Jakarta (ID): Badan Perencanaan Pembangunan Nasional.

[Bappenas] Badan Perencanaan Pembangunan Nasional. 2015b. Laporan Analisis Daya Saing UMKM di Indonesia. Jakarta (ID): Badan Perencanaan Pembangunan Nasional.

[BPDPKS] Badan Pengelola Dana Perkebunan Kelapa Sawit. 2018. Program PSR peremajaan sawit rakyat (meningkatkan produktivitas tanpa perluasan areal). Jakarta (ID): Badan Pengelola Dana Kelapa Sawit.

[Dirjenbun] Direktorat Jenderal Perkebunan. 2017. Statistik Perkebunan Indonesia 2016- 
2018: Kelapa Sawit. Jakarta (ID): Direktorat Jenderal Perkebunan Republik Indonesia

FOKSBI. 2017.

Hadiguna, RA, Machfud, Eriyatno, Suryani A, dan Arkeman Y. 2008. Manajemen rantai pasok minyak sawit mentah. Journal Logistic and Supply Chain Management. 2(1): 12-23.

Hidayat S, Marimin, Suryani A, Sukardi, Yani M. 2012. Model identifikasi risiko dan strategi peningkatan nilai tambah pada rantai pasok kelapa sawit. Jurnal Teknik Industri. 14(2): 89-96.

[Kemenperin] Kementerian Perindustrian Republik Indonesia. 2015. PP RI No 14 Tahun 2015 tentang Rencana Induk Pembangunan Industri Nasional Tahun 2015-2035. Jakarta (ID): Kementerian Perindustrian Republik Indonesia.

Malczewski J. 1999. GIS and Multicriteria Decision Analysis. Canada (USA): John Wiley\&Sons.

Marimin. 2004. Teknik dan Aplikasi Pengambilan Keputusan Kriteria Majemuk. Jakarta (ID): PT. Grasindo.

Marimin, Maghfiroh N. 2010. Aplikasi Teknik Pengambilan Keputusan dalam Manajemen Rantai Pasok. Bogor (ID): IPB Press.

Palma-Mendoza JA, Neailey K, Roy R. 2014. Business process re-design methodology to support supply chain integration. International Journal of Information Management. 34(2):167-176.

Porter ME. 1990. The Competitive Advantage of Nations. New York (USA): Harvard Business Review.

Prahasta E. 2001. Konsep-Konsep Dasar Sistem Informasi Geografis. Bandung (ID): Informatika.

Purwaningsih I. 2003. Mempelajari klaster industri: Studi kasus di industri kulit DI Yogyakarta. Jurnal Teknologi Pertanian. 4 (3): 179-192.

[PPKS] Pusat Penelitian Kelapa Sawit. 2017. Teknis peremajaan kelapa sawit. Dalam: World Plantation Conference and Exhibition. Jakarta: 18-20 Oktober 2017.

Raharjo PD, Hidayat E, Wniduhutomo S, Widiyanto K, Puswanto E. 2014. Penggunaan model analytical hierarchy process untuk penentuan potensi ancaman longsor secara spasial. Prosiding Pemaparan Hasil Penelitian Pusat
Penelitian Geoteknologi LIPI Tahun 2014. ISBN 978-979-8636-23-3.

Saaty TL. 2008. Decision making with the analytic hierarchy process. International Journal Services Science. 1(1): 83-98.

Saragih B. 2017. Oil palm smallholders in Indonesia: origin, developments strategy, and contribution to the national economy. Dalam: World Plantation Conference and Exhibition di Jakarta, 18-20 Oktober.

Sargent RG. 2015. An introductory tutorial on verification and validation of simulation models. Proceedings of the 2015 Winter Simulation Conference. New York (USA): Syracuse University.

Saxena JJP, Sushil, dan Vrat P. 1992. hierarchy and classification of program plan elements using interpretative structural modelling. System Practice. 5(6): 651-670.

Suharjito dan Marimin. 2012. Model kelembagaan pengembangan industri hilir kelapa sawit. Jurnal Teknobisnis. 7(1): 20-40.

Suroso AI, Seminar KB, dan Satriawan P. 2004. Pengembangan sistem informasi geografis untuk pengelolaan perkebunan kelapa sawit. Jurnal Manajemen dan Agribisnis. 1 (1): 3341.

Teniwut YK, Marimin M, Indrasti NS. 2017. Spatial intelligent decision support system fo increasing productivity on natural rubber agroindustry by green productivity approach. International Journal of Productivity and Performance Management. 66 (6): 1-35.

Utama DN. 2012. Sistem perencanaan manajemen rantai pasok cerdas industri bioenergi untuk mendukung klaster industri hilir kelapa sawit [Disertasi]. Bogor (ID): Institut Pertanian Bogor.

Wei LC. 2017. Concept of oil palm replanting program. Dalam: World Plantation Conference and Exhibition di Jakarta, 18 Oktober.

Weiner IB, Craighead WE. 2010. TheCorsini Encyclpodia of Physcology: 4th edition. New Jersey (USA): John Wiley\&Sons Inc.

Zulafwan. 2016. Sistem informasi geografis pemetaan perkebunan sawit berbasis web. Riau Journal of Computer Science. 2(2): 716. 